\title{
What Makes a Quotation Familiar?
}

\section{David Isaacson \\ Guest Columnist}

Correspondence concerning this column should be addressed to: Editor Diane Zabel, Schreyer Business Library, The Pennsylvania State University, 309 Paterno Library, University Park,PA 16802; e-mail:dxz2@psu.edu. David Isaacson is a retired Humanities Librarian, Waldo Library, Western Michigan University, Kalamazoo.
This is the debut of an occasional column exploring topics outside the purview of Reference \& User Services Quarterly's regular columns.-Editor

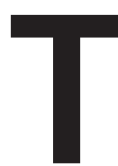

he ideal college is Mark Hopkins at one end of a log and a student at the other." This quotation-or something close to it-has become virtually a slogan among advocates of a liberal education. Even if you don't know who Mark Hopkins was-and I used this quotation for years without knowing anything about him-you get the point with this homely image: Hopkins is the kind of professor who takes the time to really get close to his students. He's not just chatting with students; he's sitting on a log with them. Those of us who like this quotation use it because it has the appeal of a rich, seemingly historical tradition; even if the tête-à-tête between student and teacher took place a long time ago, the symbolic force of the image is still pertinent today. Mark Hopkins sitting on a log with a student seems to combine the grandeur of myth with the homespun quality of a folktale. It also suggests a parable-quintessentially American-about what a real education should be. Even if Mark Hopkins did not in actual fact sit on a log with a student, we want the story to be true.

This aphorism is often used by humanists to criticize penurious "educationists" who are more concerned with academic infrastructure than with people. The idyllic image of the log, student, and teacher is rhetorically very effective-we are churlish if we think a genuine college education requires anything more than the basic ingredients of a teacher and a student. Mark Hopkins and a presumably attentive student thus serve as an ideal symbolic image of an egalitarian, rustic, albeit rather sentimentalized, vision of a college education.

Am I reading too much into this simple image? I don't think so. That's what memorable quotations are all about: they resonate with associations. I think we can argue that the parable I have imagined functions as a significant, albeit minor, work of American cultural and intellectual history.

When the ideal professor-student relationship is pictured so compellingly, who wouldn't want to have a one-on-one with an illustrious scholar-teacher like Mark Hopkins? It turns out that documented history gives credence to the tale I've imagined. Hopkins was a classics professor who was also president of Williams College from 1836 to 1872. This proverbial log image was apparently coined by James Abram Garfield, himself a professor of classics, and later the twentieth president of the United States.

Until I looked up the quotation recently, I did not know exactly who Hopkins was, let alone that Garfield apparently 
was the author of it. I had read this quotation and even used it once, with what I thought was considerable rhetorical success, at a convention of academic librarians. I stood up as a member of the audience in the question-and-answer period after a panel presentation proposing that librarians act as tutors to students. It pleased me to tell the panel that the innovative tutorial system they thought they were originating had already been invented years ago by Mark Hopkins when he sat on a log with a student. At that time my rhetorical point was made, not because I knew anything about who the real Mark Hopkins was, but simply because the quotation I remembered had the lofty-but-homely associations I've just described. (Oh, yes, it helped my cause that I said the words in a way strongly suggesting I did know what I was talking about.)

I now can claim to know a little more about this quotation and about the real Mark Hopkins. It turns out that there are some interesting differences between the actual Mark Hopkins and the imaginary one I have just described. The real Mark Hopkins published a number of books about ethics as well as being a teacher of Greek and Latin, but he was not a renowned scholar. His reputation both as teacher and president of Williams College centered on his conviction that education of the spirit was more important than education of the intellect. ${ }^{1}$ Hopkins did try to motivate his students to think for themselves, but he also tried to indoctrinate them with a no-nonsense, muscular, evangelical Christian faith. The boys-on their way to becoming men-loved Hopkins because he did not make them recite their lessons, but really tried to get to know them as individuals. In the early years, Williams College was more like a Sunday school than what we now regard as a liberal arts college. Although the school never became a church college, and only a small number of the trustees were clergymen, Hopkins gave regular sermons and held weekly religious meetings with students while he was president.

My idyllic vision of Hopkins (which, I suspect, is that of many others who only know him through the log quotation) when contrasted with the facts as Rudolf presents them, is one that Hopkins meant posterity to have. We remember the log quotation more than the books Hopkins wrote because he had a greater influence as a teacher and college president than he had as a scholar. Just as interesting, however, is that the actual quotation may not be as compact as the one I've been dissecting.

Although it is not generally known outside of our profession, a good case can be made that librarians are at least as concerned with literary forms and genres as literary scholars are. But instead of paying close attention to the genres of poetry, fiction, drama, and essays, reference librarians insist on the significance of bibliographic genres or formats. We make distinctions among dictionaries, encyclopedias, indexes, abstracts, bibliographies, annotated bibliographies, bibliographies of bibliographies, and other reference formats that almost suggest we think these categories are Platonic forms. Quotations are an especially intriguing genre. Famous or familiar quotations are a subset of the larger category of quotations, which, of course, simply means words that are cited and repeated for some reason.

One of my purposes here is to suggest that familiar quotations may not be as familiar as many people think. In fact, it is often especially difficult to authenticate the exact form of a supposedly familiar or famous quotation. I discovered that the quotation "the ideal college is Mark Hopkins at one end of a log and a student at the other" is not necessarily accurate. Garfield's actual words may not have been as memorable. Does this make the attributed quotation a misquotation? Yes, strictly speaking, it does. Does this make the misquotation a fabrication? Well, yes and no. Not trusting my memory to get the quotation exactly right, I decided to do a quick search via Google. One of my first hits on Google confirmed that the quotation is the familiar: "The ideal college is Mark Hopkins on one end of a log and a student on the other." The source listed is "Me and My Professor," an article by Scott Smallwood, in the February 15, 2002 issue of the Chronicle of Higher Education. ${ }^{2}$ Smallwood says this quotation has "almost mythic significance" at Williams College because the tutorial relationship between Hopkins and students is still very much alive there today. At the time of Smallwood's article, there was even a sculpture in a student art exhibit of Hopkins sitting on a larger-than-life log.

Just out of curiosity, I decided to check to see if other sources cited by Google also quoted Garfield the same way. Not far down the list I found this much less catchy version: "Give me a log hut, with only a simple bench, Mark Hopkins on one end and I on the other, and you may have all the buildings, apparatus, and libraries without him." These words form the epigraph to another journal article, "Tools for Teaching: Personal Encounters in Cyberspace," by James J. O'Donnell, also published in the Chronicle of Higher Education, this from February 13, $1998 .^{3}$

Puzzled now as to which version of the quotation was correct, I finally acted like a real, old-fashioned, pre-Internet, book-oriented reference librarian. Librarians can get into some indolent, not to say sloppy, habits by trusting the Web too much. So I got up from my terminal and found the latest edition of that trusty war horse, Bartlett's Familiar Quotations, the sixteenth edition, published in 1992. This source confirms that the longer version of the quotation is, apparently, authentic. Bartlett's also says that Garfield spoke these words in an address to Williams College alumni in New York City on December 28, 1871. ${ }^{4}$ I am usually not fussy about quotations I am looking up just for my own edification, but it is often a good idea to check more than one source, just to verify that one collection of quotations, or some other presumably authoritative source, agrees with another one. If you are an assiduous scholar insisting on seeing primary documents, you might, in fact, want to examine some document closer to Garfield's speech than a second-hand account in a collection of quotations. While Bartlett's is often reliable, it is not infallible. If Garfield said these words in an address, were these remarks published, or does history have to rely on the quite possibly faulty memory of someone who only heard Garfield 


\section{FOR YOUR ENRICHMENT}

say these words? After all, anything only spoken, and not written down, is part of the oral tradition, and therefore much less subject to authentication. But in this case there don't seem to be any primary documents to consult.

So I went to another well-respected compendium of quotations, Burton Stevenson's Home Book of Quotations, the tenth edition, published in 1967. According to this source, Garfield said "A pine bench, with Mark Hopkins at one end of it and me at the other, is a good enough college for me!" While a pine bench is probably more comfortable than a log, I began to wonder about the missing allusions to buildings, apparatus, and libraries, assuming that the source quoted by James J. O'Donnell is the authentic text. And "good enough college for me!" is weak compared to the more emphatic shorter version. The exclamation mark makes this statement even weaker, suggesting that we aren't going to believe the speaker unless he shouts.

What Garfield actually said is probably impossible to verify. Stevenson has a long note of explication stating that the actual words were not written down, and that Abraham Flexner, in his book Universities, says that Hopkins himself, not Garfield, was the originator of the image and that it should read: "The ideal college consists of a log of wood with an instructor at one end and a student at the other." However, Stevenson's note goes on to say, these words have never been found in Hopkins's works, so perhaps Garfield is the source after all (in which case he probably was alluding to Hopkins's contention that a well-paid faculty was more important than buildings). But why say "log of wood" when the one word log does the job with so much more punch? And "an instructor" just doesn't measure up to Mark Hopkins, even if you have never heard of him. To work, the story has to have name recognition-even if, at first, we don't recognize the proper name.

Now the plot of my story thickens. When pressed, librarians hunting quotations can pretend they are detectives. I don't have anything like Sherlock Holmes's famous powers of ratiocination, but fortunately, others who have written books about hard-to-find quotations do. An indefatigable researcher named Ralph Keyes wrote a fascinating book, Nice Guys Finish Seventh, published in 1992, devoted to tracing the real sources of misattributed or misquoted famous sayings. ${ }^{6}$ According to Keyes, who relies on Carroll A. Wilson's article, "Mark Hopkins," in The Colophon in the spring of 1938, the probable actual author, or reviser, of this log quotation was an orator named John Ingalls. ${ }^{7}$ Ingalls was a senior at Williams when Garfield was a freshman. After Garfield's death, Ingalls, famous for creating memorable phrases, went out on the circuit with a speech, "Garfield: the Man of the People." In that speech, Ingalls said of Garfield,

He always felt and manifested a peculiar interest in his alma mater and in President Hopkins, whom he regarded as the greatest and wisest instructor of the century. "A pine log," he said, "with the student at one end and Doctor Hopkins at the other, would be a liberal education."
This version may work better for some readers by describing the log as pine, by adding the title of "Doctor" to Hopkins's name, and by referring to the more elevating ideal of a liberal education rather than the quieter ideal of a college.

Although it may sound heretical for a librarian to say this, I think it is not crucial that we determine whether Hopkins, Garfield, or Ingalls is the source of this story. As with other familiar quotations, this seems to be a case of composite authorship. Some famous quotations are like ballads-we may never know the original author. The notion of a number of authors, some known by name, others not, seems in keeping with the egalitarian spirit of this quotation. Understanding why the central image of the log, Hopkins, and a student continues to be quoted so often is more important than tracing the provenance of this quotation.

I think the meaning of this quotation is more important than the question of who said it or even what the exact words were. Long after his death, Mark Hopkins continues to serve as a model of what a fundamental liberal education is. It is of historical interest—but not of great historical significance- - to note that what Hopkins inspired and what Garfield apparently said are not the same thing that Ingalls polished up. Ingalls improved what Garfield said. It's more euphonious to say "log" or "bench" than the various longer versions of this quotation. But it wasn't only Ingalls's gift for phrase-turning that makes this quotation resonate. Each professor who values a true dialogue with students is, in effect, a cocreator of this quotation. By extension, every person who agrees with the sentiment in this quotation enough to repeat it clearly perpetuates it, and thus continues to recreate it. When I alluded to Mark Hopkins, the student, and a log some years ago at the librarian's conference I mentioned earlier, I doubt that I quoted the words exactly as they are stated at the beginning of this essay. But I still quoted the sense of the saying accurately enough.

Even though the longer, less memorable version of Garfield's remarks appears, according to Stevenson, to be historically accurate, and Ingalls's pithier revision is therefore perhaps not true, what history remembers is the fabrication. It sticks in our memory not only because it is shorter, but because the concrete image of the log is so vivid. Furthermore, we want to believe in this image of a close encounter between the impressive professor and the presumably receptive student.

I can hear someone objecting that I have no right to dismiss the significance of the question of authenticating the speaker and his exact words. The general public, not just historians and reference librarians, need to be able to rely on some authorities to verify quotations. It's one thing to make the case for the staying power of a well-turned phrase trumping a lame one. But it's quite another thing to support error or, worse, legend. Don't scholars have an obligation to get the facts right first?

Yes, of course, without hesitation, an old-fashioned scholar says: we don't have history without solid, documentable facts. But a newer-fashioned scholar may object: we also need to trace why there are variations on the facts. I 
have been scrupulous in tracing the different versions of the Hopkins-Garfield quotation. But many other writers, among them the two who published the articles in the Chronicle of Higher Education, simply assumed that their version of the quotation was accurate. Should whoever edited these two pieces for the Chronicle be indefatigable in seeking not simply a published source verifying quotations like this, but a believable published source? Surely, because this quotation is in the public domain, it doesn't really matter all that much what the exact words were? Or that Ingalls may have improved what Garfield said, if, in fact, Garfield, rather than Hopkins himself, said the original words?

If one is litigious, I suppose a case can be made that Ingalls, while improving the lackluster original words of Garfield and Hopkins, committed a minor form of plagiarism. The fact that his revision sounds better than Garfield's is beside the point if the main question is distinguishing the difference between what is true and what someone would like the truth to be.

Now, someone will counter-argue, there's quite a difference between out-and-out plagiarism and polishing up a quotation. Isn't what Ingalls did to the quotation by the deceased Garfield similar to what speechwriters do for a living president every time they write a speech? Ted Sorensen apparently wrote some of John F. Kennedy's inaugural address, but history has no problem attributing "ask not what your country can do for you but what you can do for your country" to Kennedy. There is, one assumes, little chance that Sorensen will sue the Kennedy estate for infringement of copyright, because presumably the Kennedy estate, not Sorensen, owns the words attributed to the president in the inaugural address, and because the public has entered into an agreement with history (and with Sorensen) to attribute the words to Kennedy.

With famous or so-called familiar quotations, we often do not know how the words became famous or familiar. Some of the best-remembered quotations have been said or written by that ever ubiquitous and always untraceable writer, Anonymous. Anyone who quotes familiar words risks the danger of being at least somewhat unfamiliar with the actual quotation. Quotations involving familiar words are something like stock market quotations- they are subject to unpredictable changes.

The dishonest or simply lazy student should not be allowed to claim credit for stolen words. But it seems that any of the versions of the Hopkins quotation I've cited can be legitimately claimed as genuine. A very good argument can be made that Ingalls's version, because it is snappier, is the "right" one. If we insist on quoting the Ingalls version despite knowing that there are alternative wordings, we seem to be indulging in revisionist history. But if this is true, all of us are revisionists.

This may sound as if I am paying too much attention to the rhetorical effects of this quotation and not enough attention to its existence as a document. Perhaps I sound like a deconstructionist or postmodern critic. But I think de- constructionists might unwittingly destroy, rather than just deconstruct this quotation, because they would have us pay attention to all of the possible interpretations of a text. If I understand deconstructive hermeneutics correctly, the various interpretations of a text are the text. No interpretation, no text. No, it's more complicated even than that: no interpreter, no text. If a quotation is uttered in a forest and no one hears it, does that quotation exist? If a quotation is published but no one reads it, does that quotation exist? Some politically correct literary critics insist they can only teach "the controversy" about a work of literature, not just one perspective on that work. If this is the proper way to approach a complex and controversial work of literature like Heart of Darkness, then why not other famous, but comparatively minor texts-such as the Hopkins quotation-as well?

At this point in what I take to be deconstructionist reasoning, I give up. I am tempted to assert rather than argue, to kick a stone, as Samuel Johnson purportedly did when told that Hume didn't believe the real world existed, and reply to those who insist that all of these Hopkins quotations are in some sense correct, "I refute you thus." The stone I just kicked is quite solid: if a phrase rolls nicely off the tongue, people are more likely to remember it. The general educated public, because it is more pleased by well-formulated words than by awkward ones, is much more likely to remember some combination of words including Mark Hopkins, a student on a log, and a college, university, or a liberal education, rather than a combination of the less memorable set of words that includes Hopkins, a student, a pine bench, a library, the vague word "apparatus," and classrooms.

I think we can conclude that if a saying is to be familiar it is necessary to construct it well. There is very little chance an awkwardly written group of words will be remembered better than an alternative set with a nice ring to them. Even if the bons mots were not said by a famous person, they may be attached to a famous person's name. This is due to the fascination we have with famous people. We assume that because they are famous for performing certain deeds, they may also be famous for saying or writing memorable words. It is sometimes the case that an otherwise unknown person may achieve a certain fame simply for saying something uncommonly well. However, even when no famous or unknown author can be found, there is a mysterious creative process at work in the vox populi that often imagines, shapes, revises, and polishes otherwise unmemorable words until they become memorable. If John Ingalls is the actual final author of the Hopkins quotation, as Ralph Keyes suggests, most people don't know that. A few more may know, or think they know, that James A. Garfield said "the ideal college is Mark Hopkins at one end of a log and a student at the other." But there are many other quotations where we will never know the name of the person who takes on Ingalls's job of revision. We don't always know the name of a speechwriter who made a president's words more presentable. There are many unnamed people who have a gift for words. That's what's so fascinating about collaborative or collective authorship. It is 


\section{FOR YOUR ENRICHMENT}

frustrating to a historian, archivist, biographer, or reference librarian who wants to get all the facts right, but it is a wondrous thing for the literary critic and the historian of ideas to speculate about. The common folk often speak with native elegance-probably because they were taught by a patient teacher like Mark Hopkins.

\section{References}

1. Frederick Rudolf, Mark Hopkins and the Log: Williams College, 1836-1872 (Williamstown, Mass.: Williams College, 1996); D. H. Meyer, The Instructed Conscience: The Shaping of the American National Ethic (Philadelphia: Univ. of Pennsylvania Pr., 1972), 64-65.
2. Scott Smallwood, "Me and My Professor: Oxford Style Tutorials," Chronicle of Higher Education 43 (Feb. 15, 2002): A16-A18.

3. James J. O'Donnell, "Tools for Teaching: Personal Encounters in Cyberspace," Chronicle of Higher Education 44 (Feb. 13, 1998): B87.

4. John Bartlett, Bartlett's Familiar Quotations, 16th ed. (Boston, Mass.: Little, Brown, 1992), 516.

5. Burton Stevenson, The Home Book of Quotations: Classical and Modern, 10th ed. (New York: Dodd, 1967), 2069

6. Ralph Keyes, Nice Guys Finish Seventh: False Phrases, Spurious Sayings, and Familiar Misquotations (New York: HarperCollins, 1992), 170-72.

7. Carroll A. Wilson, "Mark Hopkins," Colophon (Spring 1938), 194-208. 